\title{
Effects of Zirconia Addition on Fracture Toughness and Bending Strength of Dental Porcelains
}

\author{
Masayuki KON, Kunio ISHIKAWA and Norihiko KUWAYAMA \\ Department of Dental Engineering, School of Dentistry, Tokushima University, \\ 3 Kuramoto-cho, Tokushima, Tokushima 770, Japan
}

Received on June 12, 1990

Accepted on October 25, 1990

Zirconia dispersed composite porcelains with glass and aluminous porcelain as matrix were prepared as models of dental porcelains. The bending strength and fracture toughness of the composite porcelains were examined. The bending strength and fracture toughness of composite porcelains containing $50 \mathrm{wt} \% \mathrm{zirconia}$ were 20 to $80 \%$ greater than in glass alone. However, bending strength and fracture toughness decreased upon the addition of zirconia at more than $50 \mathrm{wt} \%$. Moreover, in the case of aluminous porcelain as matrix, fracture toughness increased to a maximum value of $2.6 \mathrm{MPa} \mathrm{m}^{1 / 2}$ by addition of $23 \mathrm{wt} \%$ zirconia, twice the toughness of glass alone. On the other hand, no increase of bending strength was observed in this case. Deflection and bowing of cracks as well as microcracking effects were related to these increases of mechanical properties in zirconia dispersed composite porcelains.

Key words : Porcelain, Zirconia, Mechanical property

\section{INTRODUCTION}

Porcelain has many applications in restorative dentistry including denture teeth, jacket crowns, porcelain-fused-to-metal bridge work, and inlays. Porcelain possesses excellent esthetics and resists mechanical wear and chemical degradation extremely well. However, conventional dental porcelain is weak with respect to shearing as it essentially is a brittle material. In order to compensate for this brittleness, various methods, including baking on metal and production in or addition of crystal to the glass matrix have been proposed. Garvie et al. reported high strength zirconia ceramics made from room-temperature-stable tetragonal zirconia in $1975^{11}$. Since then fracture resistant ceramics which can overcome the disadvantages of brittleness have been the subject of considerable interest. In particular, significant attention has focussed on partially stabilized zirconia ceramics which absorb breaking energy by the transformation of tetragonal zirconia to monoclinic zirconia and possess high fracture toughness ${ }^{2-6}$. In addition, much attention has been devoted to zirconia dispersed composite ceramics in which zirconia particles are dispersed in alumina and silicon nitride ceramics ${ }^{7-12)}$. It has been observed that deflection and curving of cracks as well as microcracking can be caused by the phase transformation of zirconia and can absorb breaking energy ${ }^{7-12}$.

In 1984, we reported on the mechanical properties of composite porcelains containing dispersed zirconia particles in glass matrix as a model of dental porcelain ${ }^{13}$. R. Morena $e t$ $a l$. also reported the fracture toughness and bending strength of dental porcelains to increase 30 to $35 \%$ upon the addition of zirconia ${ }^{14)}$. 
In the present investigation, composite porcelains containing various kinds of zirconia dispersed into 2 kinds of matrices will be discussed as models of dental porcelain. A technique for producing controlled microcracks was applied to the glass matrix and the fracture toughness and bending strength of various ceramics are reported.

\section{MATERIALS AND METHODS}

\section{Specimen Preparation}

Two kinds of glass were employed as matrix materials for porcelain models: borosilicate $\left(4 \mathrm{wt} \% \mathrm{Na}_{2} \mathrm{O}-13 \mathrm{wt} \% \mathrm{~B}_{2} \mathrm{O}_{3}-81 \mathrm{wt} \% \mathrm{SiO}_{2}\right.$ ) and soda-lime glass (14 wt \% $\mathrm{Na}_{2} \mathrm{O}-11 \mathrm{wt} \%$ $\mathrm{CaO}-73 \mathrm{wt} \% \mathrm{SiO}_{2}$ ) as summarized in Table $1^{15}$. In addition, 3 different mixtures of borosilicate glass and electro-fused alumina were used as models of alminous porcelain ${ }^{16)}$ (Table 1). Five kinds of electro-fused zirconia powders* with a mean particle size of $0.4 \mu \mathrm{m}$ were used as dispersion particles (Table 2). Glass and alumina powders used as matrices were crushed to a fine powder** in an alumina cell and their mean particle sizes were measured by an automatic particle size distribution measuring system***. Matrix materials and zirconia were then mixed in a ball mill for $1 \mathrm{~h}$ without a dispersing agent. Pressures of up to $20 \mathrm{MPa}$ were applied to dry specimens in metal dies using a mechanical press. After press

Table 1 Various matrices for zirconia dispersed composite system

\begin{tabular}{lcccc}
\hline Code & $\begin{array}{c}\text { Sodium borosilicate } \\
\text { glass } \\
(\mathrm{wt} \%)\end{array}$ & $\begin{array}{c}\text { Sodium lime } \\
\text { silicate glass } \\
(\mathrm{wt} \%)\end{array}$ & $\begin{array}{c}\text { Alumina } \\
(\text { Corundum }) \\
(\mathrm{wt} \%)\end{array}$ & $\begin{array}{c}\text { Average } \\
\text { particle size } \\
(\mu \mathrm{m})\end{array}$ \\
\hline $\mathrm{G}_{1}$ & 100 & 0 & 0 & 5 \\
$\mathrm{G}_{2}$ & 0 & 100 & 0 & 5 \\
$\mathrm{GA}_{5}$ & 50 & 0 & 50 & 4 \\
$\mathrm{GA}_{4}$ & 60 & 0 & 40 & 4 \\
$\mathrm{GA}_{3}$ & 70 & 0 & 30 & 4 \\
\hline
\end{tabular}

Table 2 Various zirconia specimens used in this study

\begin{tabular}{ll}
\hline Zirconia & Code \\
\hline $\mathrm{ZrO}_{2}$ & $\mathrm{Zm}$ \\
$\mathrm{ZrO}_{2}+\mathrm{Y}_{2} \mathrm{O}_{3}(6.5 \mathrm{wt} \%)$ & $\mathrm{ZYc}$ \\
$\mathrm{ZrO}_{2}+\mathrm{Y}_{2} \mathrm{O}_{3}(4.1 \mathrm{wt} \%)$ & $\mathrm{ZYt}$ \\
$\mathrm{ZrO}_{2}+\mathrm{CaO}(5.5 \mathrm{wt} \%)$ & $\mathrm{ZCc}$ \\
$\mathrm{ZrO}_{2}+\mathrm{CaO}(3.5 \mathrm{wt} \%)$ & $\mathrm{ZCt}$ \\
\hline
\end{tabular}

$\mathrm{m}:$ monoclinic

$c:$ cubic

$\mathrm{t}$ : tetragonal

\footnotetext{
* Tateho Chemical Industries Co., Okayama, Japan

** T-100 model Vibrating sample mill, Heiko Seisakusyo, Ltd., Fukushima, Japan

*** CAPA-300 Centrifugal automatic particle analyzer, Horiba, Ltd., Kyoto, Japan
} 
drying, compacts were sintered at a rate of $5^{\circ} \mathrm{C} \cdot \mathrm{min}^{-1}$ in atmosphere.

Dense Temperature

The linear shrinkage of pressed samples of $8 \phi \times 10 \mathrm{~mm}$ was measured by constant heating at a rate of $5^{\circ} \mathrm{C} \cdot \mathrm{min}^{-1}$ to $1300^{\circ} \mathrm{C}$. Dense temperature was determined by linear shrinkage $v s$ the temperature curve. The density of the sintered porcelains was measured by Archimedes' method.

\section{SEM Observations}

The microstructure of the destroyed surface of sintered materials was also observed with a scanning electron microscope"

\section{Mechanical Properties}

Test pieces for the measurement of mechanical properties were made by grinding the surface of a test piece flat and smooth using \# 700 diamond rap. The sizes of the test pieces were $2 \mathrm{~mm} \times 6 \mathrm{~mm} \times 15 \mathrm{~mm}$ and $4 \mathrm{~mm} \times 6 \mathrm{~mm} \times 15 \mathrm{~mm}$ for the bending strength and fracture toughness tests, respectively. In measuring fracture toughness $\left(\mathrm{K}_{\mathrm{IC}}\right), 10$ specimens at each $\mathrm{ZrO}_{2}$ content were notched to a depth of $1.0 \mathrm{~mm}$ and thickness of $0.2 \mathrm{~mm}$ with diamond wheel ${ }^{*}$ at a slow speed. Unnotched specimens were used to measure bending strength. Both fracture toughness and bending strength specimens were tested for 3-point bending * * over a $15 \mathrm{~mm}$ span at a crosshead speed of $0.5 \mathrm{~mm} \cdot \mathrm{min}^{-1}$. The fracture toughness of the sintered materials was calculated using the Single-Edge-Notched-Beam (SENB) method ${ }^{17)}$.

\section{$X$-Ray Diffraction}

The X-ray powder diffraction patterns (XRD) of sintered materials were recorded. The diffractometer sysyem ${ }^{\# \# \#}$ employed used $\mathrm{Ni}$-filtered $\mathrm{Cuk} \alpha$ radiation. The $2 \theta$ range from $10^{\circ}$ to $70^{\circ}$ was covered at a scanning speed of 1.0 degree $\min ^{-1}$ at $30 \mathrm{kV}$ and $10 \mathrm{~mA}$.

\section{RESULTS AND DISCUSSION}

\section{Zirconia Dispersed Glass Porcelain}

The dense temperatures of borosilicate and soda-lime glass were $800^{\circ} \mathrm{C}$ and $730^{\circ} \mathrm{C}$, respectively ${ }^{15,18)}$. The sintering temperature of these glasses rose as the amount of added zirconia increased. In the case of composite porcelains containing $50 \mathrm{wt} \%$ zirconia, dense temperatures were from $880^{\circ} \mathrm{C}$ to $1050^{\circ} \mathrm{C}$. On the other hand, composite porcelains containing $60 \mathrm{wt} \%$ zirconia showed rather high dense temperatures, from $1100^{\circ} \mathrm{C}$ to $1170^{\circ} \mathrm{C}$. Zircon $\left(\mathrm{SiZrO}_{4}\right)$ was produced by the reaction between zirconia and a glass component, i. e. silica, at high sintering temperatures. In the case of stabilized and partially stabilized zirconia with calcia (ZCc, ZCt), the amount of cubic-zirconia decreased with sintering. On the other hand, partially stabilized zirconia with yttria $(\mathrm{ZYt})$ in the cubic-zirconia phase increased with sintering. The binding strengths and fracture toughnesses $\left(\mathrm{K}_{\mathrm{IC}}\right)$ of the composite ceramics containing $50 \mathrm{wt} \%$ zirconia are summarized in Table 3 . In the case of borosilicate glass

\footnotetext{
"S-700 Scanning electron microscope, Hitachi Co., Tokyo, Japan

* MC-411 Crystal cutter, Maruto Co., Ltd., Tokyo, Japan

\# \# AGS-500A Autograph, Shimazu Co., Kyoto, Japan

* \# * ADG-301, Toshiba Co., Tokyo, Japan
} 
Table 3 Bending strength and fracture toughness values for glass-zirconia composite systems

\begin{tabular}{|c|c|c|c|c|c|c|c|c|c|c|}
\hline \multirow{2}{*}{$\begin{array}{l}\text { Glass } \\
\quad(50 \mathrm{wt} \%) \\
\text { Zirconia }\end{array}$} & \multicolumn{5}{|c|}{$\mathrm{G}_{1}$} & \multicolumn{5}{|c|}{$\mathrm{G}_{2}$} \\
\hline & $\mathrm{Zm}$ & $Z Y c$ & $\mathrm{ZYt}$ & $Z \mathrm{Cc}$ & $\mathrm{ZCt}$ & $\mathrm{Zm}$ & $Z Y c$ & $\mathrm{ZYt}$ & $\mathrm{ZCc}$ & $\mathrm{ZCt}$ \\
\hline $\begin{array}{l}\text { Bending strength } \\
(\mathrm{MPa})\end{array}$ & $\begin{array}{l}70 \\
(8)\end{array}$ & $\begin{array}{l}134 \\
(8)\end{array}$ & $\begin{array}{l}99 \\
(4)\end{array}$ & $\begin{array}{l}128 \\
(10)\end{array}$ & $\begin{array}{l}118 \\
(11)\end{array}$ & $\begin{array}{l}130 \\
(17)\end{array}$ & $\begin{array}{l}112 \\
(9)\end{array}$ & $\begin{array}{l}92 \\
(2)\end{array}$ & $\begin{array}{l}110 \\
(9)\end{array}$ & $\begin{array}{l}123 \\
(11)\end{array}$ \\
\hline $\begin{array}{l}\text { Fracture toughness } \\
\mathrm{K}_{1} \mathrm{c}\left(\mathrm{MPa} \cdot \mathrm{m}^{1 / 2}\right)\end{array}$ & $\begin{array}{c}1.72 \\
(0.18)\end{array}$ & $\begin{array}{c}2.03 \\
(0.10)\end{array}$ & $\begin{array}{l}1.85 \\
(0.11)\end{array}$ & $\begin{array}{c}2.03 \\
(0.03)\end{array}$ & $\begin{array}{c}2.22 \\
(0.49)\end{array}$ & & & & & \\
\hline
\end{tabular}

matrix $\left(\mathrm{G}_{1}\right)$, dispersion of unstabilized zirconia $(\mathrm{Zm})$ resulted in a minimum bending strength of $70 \mathrm{MPa}$, similar to that of $\mathrm{G}_{1}$ glass alone, at $60 \mathrm{MPa}$. The highest values of bending strength were achieved with yttria or calcia stabilized zirconia $(\mathrm{ZYc}, \mathrm{ZCc})$, at about 134 and $128 \mathrm{MPa}$, respectively. These values are twice that of matrix alone ${ }^{18,19)}$. In the $50 \mathrm{wt} \%$ partially stabilized zirconia system, bending strengths were 99 and $118 \mathrm{MPa}$, respectively. These results show that the bending strength of zirconia composite porcelains of $G_{1}$ glass increase with increased in cubic phase zirconia.

Differing results were obtained when soda-lime glass $\left(\mathrm{G}_{2}\right)$ was used as matrix. In such cases, the maximum bending strength was observed in composite porcelains with unstabilized zirconia $(\mathrm{Zm})$ at $130 \mathrm{MPa}$ and bending strengths between 90 and $120 \mathrm{MPa}$ were obtained with other zirconia composite porcelains. One reason mechanical strengths may differ between the 2 glass matrix groups depending on the kind of zirconia may be that the glass and zirconia components are different and differing reactions at firing temperature may, in turn, result in differences of mechanical strength ${ }^{15,19)}$. Fracture toughness $\left(\mathrm{K}_{\mathrm{IC}}\right)$ of all $\mathrm{G}_{1}$ glass-zirconia composite ceramics was higher than in sintered materials of glass alone ${ }^{13,20}$, at $1.32 \pm 0.13$ $\mathrm{MPa} \cdot \mathrm{m}^{1 / 2}$. In the case of composite ceramics containing $50 \mathrm{wt} \%$ zirconia, fracture toughness as high as $2 \mathrm{MPa} \cdot \mathrm{m}^{1 / 2}$ was obtained. In the case of composite ceramics containing hard crystal, e.g. glass-alumina composite porcelains, high mechanical strengths and toughnesses were obtained by the deflection and bowing of main cracks induced by destruction ${ }^{7-12,21-29)}$. In this way, both bending strength and fracture toughness increased. In this experiment as well, both bending strength and fracture toughness was much greater than that of ceramics with glass alone. Thus, main cracks causing destruction may be deflected by dispersed particles, and the crack front proceeding around the latter, requiring more energy ${ }^{7,12,21-29)}$. The bending strength and fracture toughness of composite porcelains containing more than $50 \mathrm{wt} \%$ zirconia were lower than those of composite porcelains containing only $50 \mathrm{wt} \%$ zirconia (Table 4). The reason for this decreasing strength and toughness may have to do with the crystallization of zircon in composite porcelains ${ }^{19)}$.

\section{Zirconia Dispersed Aluminous Porcelain}

The bending strength of $\mathrm{G}_{1}$ glass-alumina (GA) composite porcelains increases with increases in added alumina, reaching a maximum of $180 \mathrm{MPa}$ at $50 \mathrm{wt} \%$ alumina ${ }^{18,19)}$. Fracture toughness changes in a similar fashion as bending strength, as shown in FIg. 1, reaching a maximum of $2.11 \mathrm{MPa} \cdot \mathrm{m}^{1 / 2}$ when $50 \mathrm{wt} \%$ alumina is added. The shrinkage curves of powder compacts of aluminous porcelain containing $40 \mathrm{wt} \%$ alumina $\left(\mathrm{GA}_{4}\right)$ and various 
Table 4 Bending strength and fracture toughness values for $G_{1}$ glasszirconia composite systems

\begin{tabular}{cccc}
\hline $\begin{array}{c}\text { Zirconia } \\
\text { (code) }\end{array}$ & $\begin{array}{c}\text { Content } \\
(\mathrm{wt} \%)\end{array}$ & $\begin{array}{c}\text { Bending strength } \\
(\mathrm{MPa})\end{array}$ & $\begin{array}{c}\text { Fracture toughness } \\
\mathrm{K}_{\mathrm{lc}}\left(\mathrm{MPa} \cdot \mathrm{m}^{1 / 2}\right)\end{array}$ \\
\hline $\mathrm{Zm}$ & 55 & $71(6)$ & $1.44(0.06)$ \\
$\mathrm{ZYc}$ & 60 & $103(11)$ & $1.56(0.04)$ \\
$\mathrm{ZYt}$ & 55 & $89(7)$ & $1.80(0.12)$ \\
$\mathrm{ZCc}$ & 60 & $60(3)$ & $1.16(0.05)$ \\
ZCt & 55 & $56(4)$ & $1.86(0.13)$ \\
\hline & &
\end{tabular}

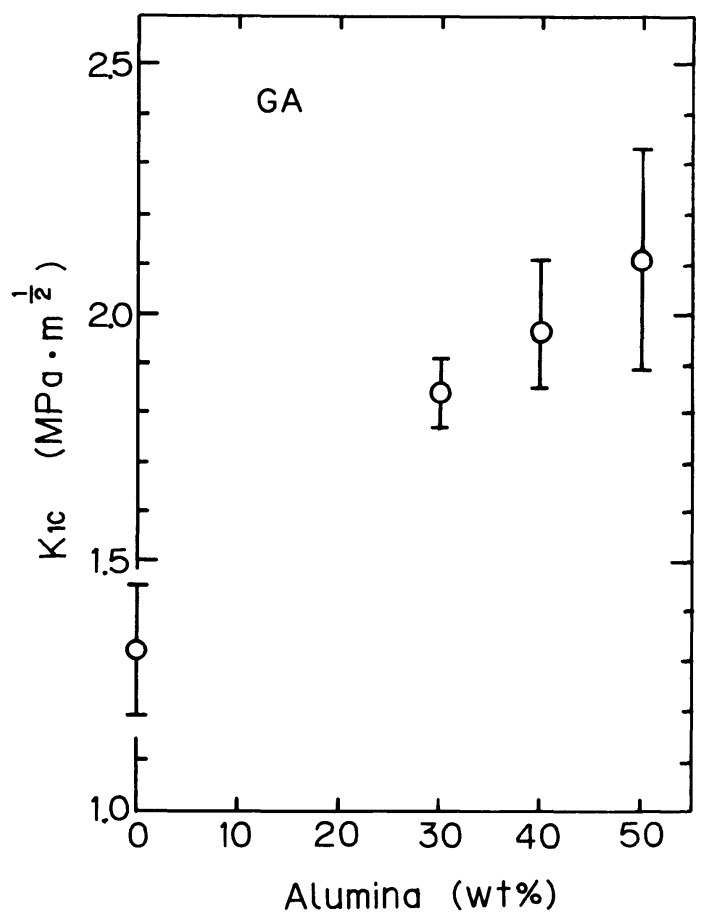

Fig. 1 Relation between fracture toughness $\left(\mathrm{K}_{\mathrm{IC}}\right)$ and alumina content of glassalumina composite porcelains.

additions of ZYt-zirconia are summarized in Fig. 2. Shrinkage curves and sintering temperatures as well increase with zirconia addition. Similar phenomena were observed for $\mathrm{GA}_{3}$ and $\mathrm{GA}_{5}$ matrix as well as for other zirconia. Crystals other than row materials were not detected in composite porcelains fired below $1100^{\circ} \mathrm{C}$, though zircon, produced by a reaction between zirconia and silica, was detected by X-ray diffraction analysis in composite porcelains fired above $1200^{\circ} \mathrm{C}$. The amount of zircon was affected by the kinds of zirconia added. The porosity of the glass-alumina-zirconia composite porcelains increased with increases of added zirconia. The typical porosity of the composite porcelains are summarized in Fig. 3 for 


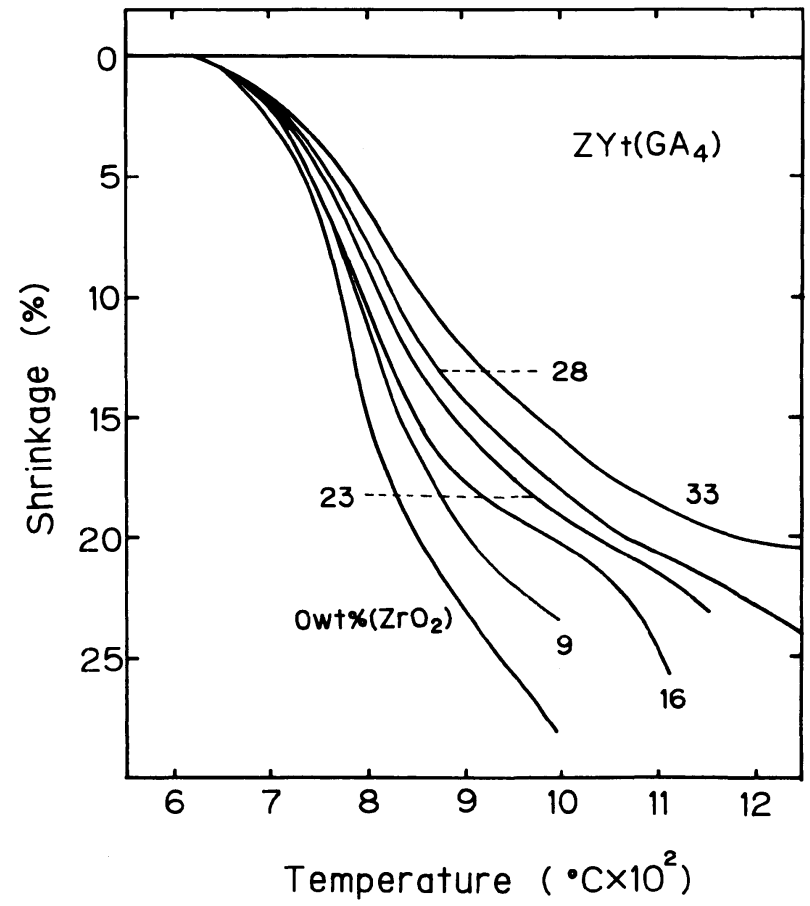

Fig. 2 Changes in firing shrinkage curves of powder compacts consisting of glassalumina matrix $\left(\mathrm{GA}_{4}\right)$ and zirconia $(\mathrm{ZYt})$, with temperature raised continuously.

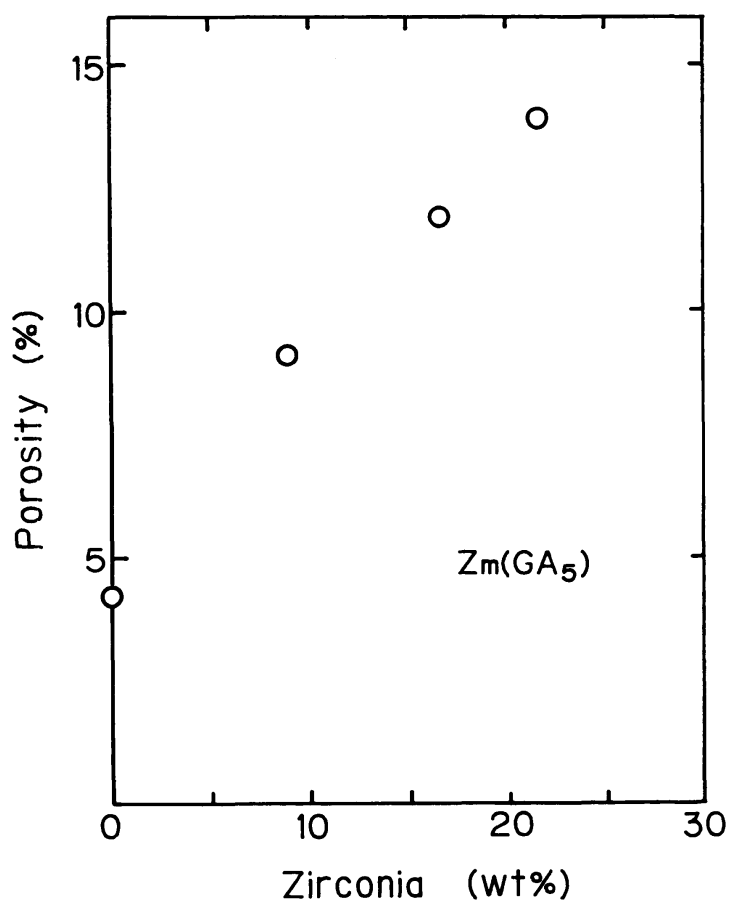

Fig. 3 Relation between porosity and zirconia content of sintered specimens consisting of glass-alumina matrix $\left(\mathrm{GA}_{5}\right)$ and zirconia $(\mathrm{Zm})$. 
the $\mathrm{GA}_{5}$-zirconia system and the bending strengths of the $\mathrm{GA}_{5}-\mathrm{Zm}$ composite porcelains are summarized in Fig. 4. The bending strength of $\mathrm{GA}_{5}$ matrix alone was about $180 \mathrm{MPa}$ but decreased upon zirconia addition to about $110 \mathrm{MPa}$ at $33 \mathrm{wt} \%$ zirconia. One reason bending strength decreases may be that porosity increases as zirconia is added ${ }^{30)}$ (Fig. 3). On the other hand, the fracture toughness of the $\mathrm{GA}_{5} \cdot \mathrm{Zm}$ composite porcelains was constant up to $16 \mathrm{wt}$ zirconia and equal to that of matrix alone as shown in Fig. 5 . At $23 \mathrm{wt} \%$ zirconia, a maximum value of $2.57 \mathrm{MPa} \cdot \mathrm{m}^{1 / 2}$ was obtained for fracture toughness, and further addition of zirconia over $23 \mathrm{wt} \%$ caused fracture toughness to decrease (Fig. 5). In order to observe the microstructure of the surface of destroyed composite porcelains, scanning electron microscopy (SEM) was conducted. As shown in Fig. 6, deflection and bowing of cracks were seen to occur before destruction. However, microcracks due to transformation of zirconia phase were not observed by SEM. Increases in fracure toughness occur with the microcracking effect as maximal fracture toughness is observed at a zirconia content accompanied by a decrease in bending strength ${ }^{10,12)}$. The microcracks in zirconia dispersed ceramics are formed by the expansion of zirconia particles during the tetragonal $\rightarrow$ monoclinic phase transformation. Toughening with the microcracking effect is explained by fracture energy absorption in a microcrack zone, as microcrack opening and branching of main cracks causing destruction ${ }^{7,8,10,12,23,27,31}$. The reason for the decreasing fracture toughness in the case of $\mathrm{GA}_{5}-\mathrm{Zm}$ composite system containing more than $23 \mathrm{wt} \%$ zirconia may have to do with existence of large cracks that the microcracks join up between the particles in a composite

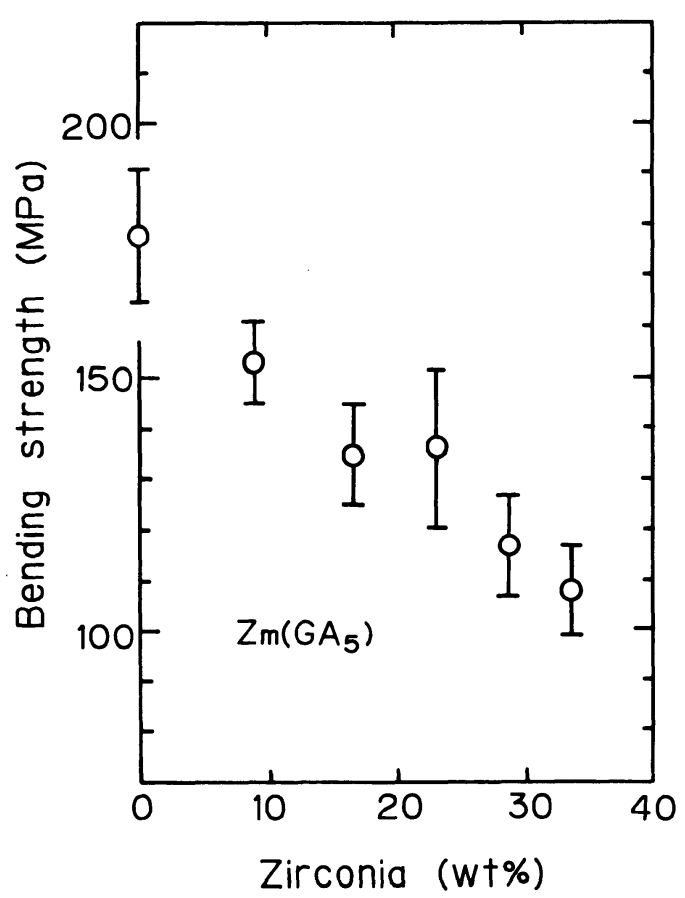

Fig. 4 Relation between bending strength and zirconia content of sintered composite systems consisting of glass-alumina matrix $\left(\mathrm{GA}_{5}\right)$ and zirconia $(\mathrm{Zm})$. 


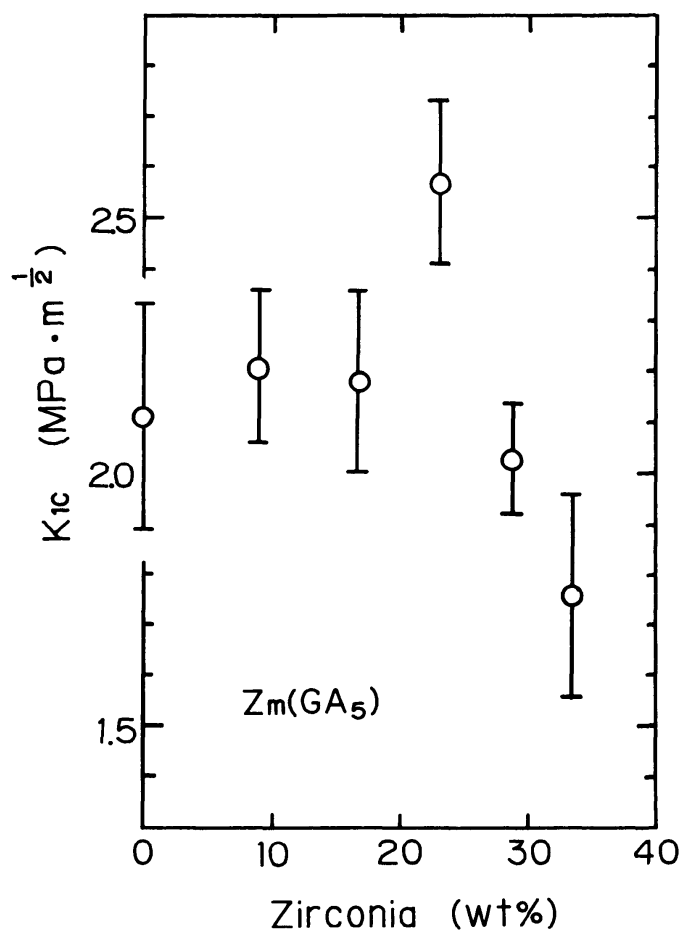

Fig. 5 Relation between fracture toughness $\left(\mathrm{K}_{\mathrm{IC}}\right)$ and zirconia content of sintered composite systems consisting of glass-alumina matrix $\left(\mathrm{GA}_{5}\right)$ and zirconia $(\mathrm{Zm})$.

porcelain ${ }^{10,12)}$. When yttria partially stabilized zirconia was used for the $\mathrm{GA}_{4}$-zirconia composite system, addition of ZYt had little or no effect on bending strength as shown in Fig. 7. The porosity of $\mathrm{GA}_{4}-\mathrm{ZYt}$ composite porcelains increased with increases in the amount of zirconia, but porosity values were lower than those of the $\mathrm{GA}_{5}-\mathrm{Zm}$ composite system. The fracture toughness of $\mathrm{GA}_{4}-\mathrm{ZYt}$ composite porcelains increased when compared to $\mathrm{GA}_{4}$ matrix alone, the latter's value being $2.0 \mathrm{MPa} \cdot \mathrm{m}^{1 / 2}$, while the former's value reached $2.2 \mathrm{MPa}$. $\mathrm{m}^{1 / 2}$ at $16 \mathrm{wt} \% \mathrm{ZYt}$ content (Fig. 8), The fracture toughness of $\mathrm{GA}_{4}-\mathrm{ZYt}$ composite system had a maximal point, smaller than that of $\mathrm{GA}_{5}-\mathrm{Zm}$ system (Fig. 5). This reason may as well be supplied by the microcracking effect, similar to the case of $G_{5}-Z m$ system. These results may show that the dispersion of unstabilized zirconia is more effective than that of partially stabilized zirconia in an aluminous porcelain matrix.

\section{CONCLUSIONS}

Zirconia dispersed composite porcelains with glass and aluminous porcelain as matrix were prepared as models of dental porcelain in order to assay increases in the mechanical properties of dental porcelain. The bending strength and fracture toughness of glass matrix porcelains increased $20 \%$ to $80 \%$ upon dispersion of $50 \mathrm{wt} \%$ zirconia.

In the case of aluminous matrix porcelains, fracture toughness increased 2 times, to 2.6 


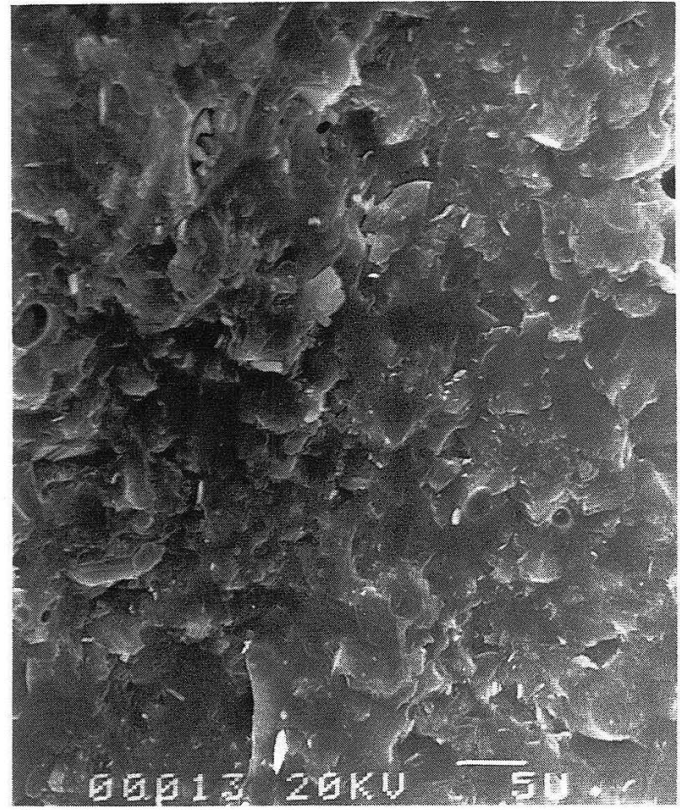

$(0 \%)$

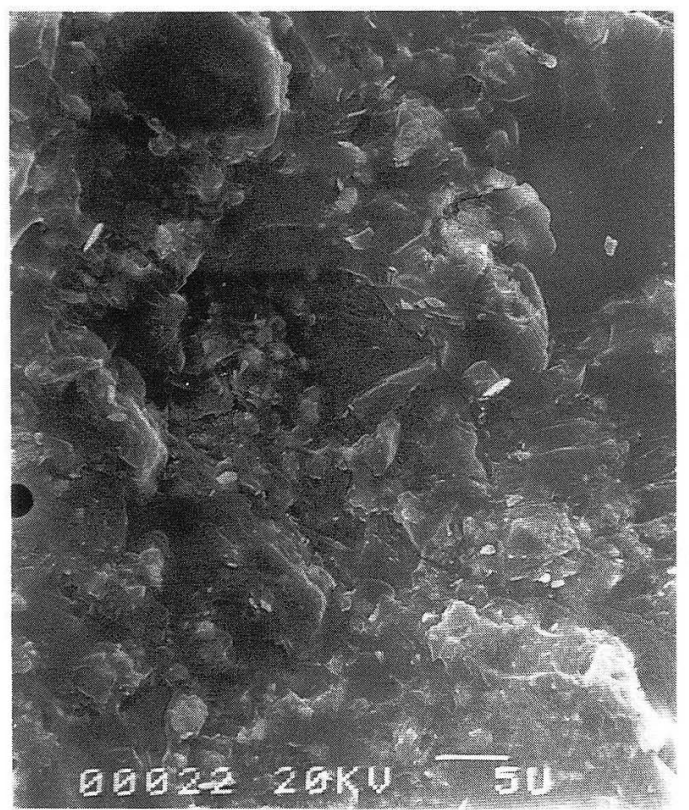

$(16 \%)$

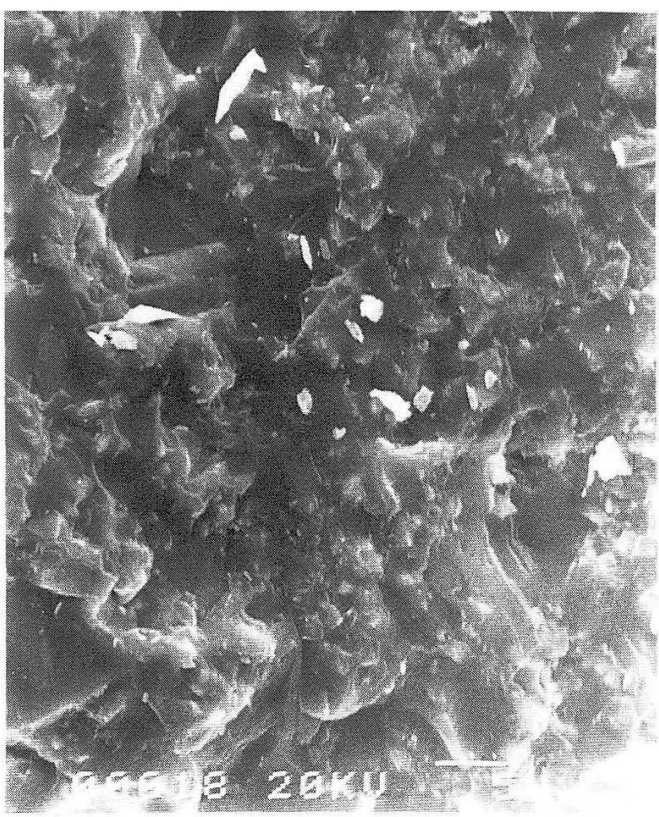

$(9 \%)$

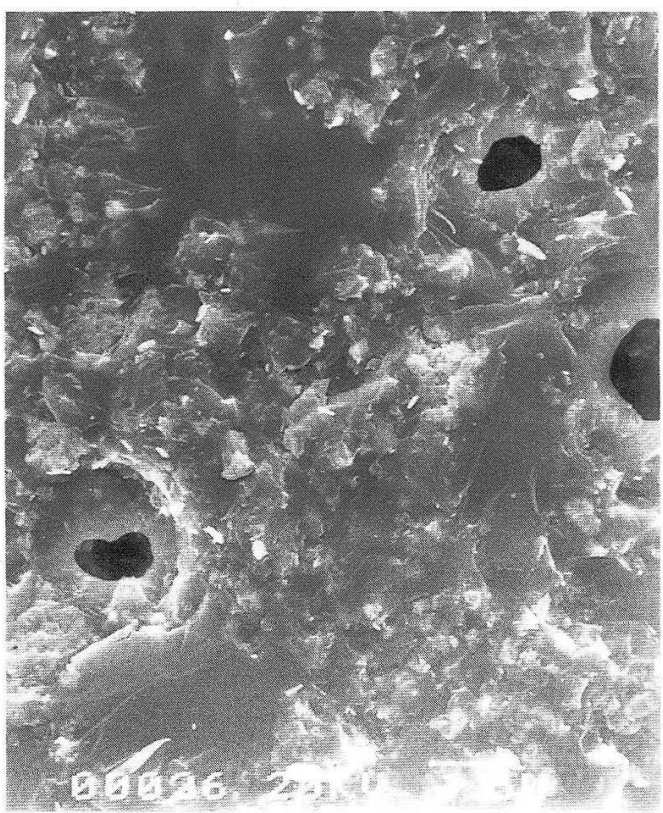

$(23 \%)$

$\mathrm{GA}_{5}-\mathrm{Zm}$ composite system ( $\mathrm{Zm}$ content wt\%)

Fig. 6 Microstructure (SEM) of sintered composite systems consisting of glassalumina matrix $\left(\mathrm{GA}_{5}\right)$ and zirconia $(\mathrm{Zm})$. 


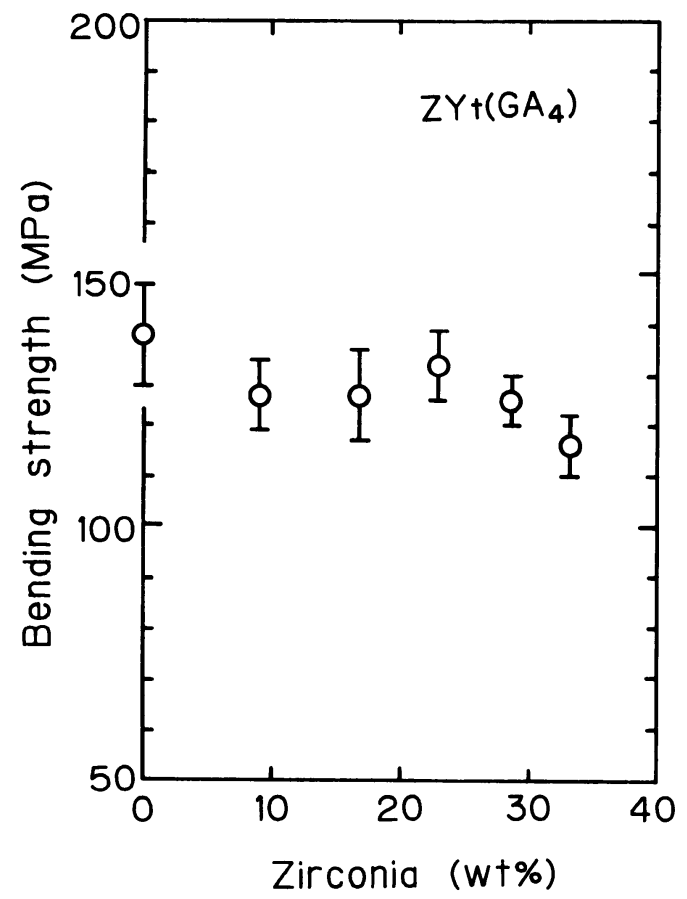

Fig. 7 Relation between bending strength and zirconia content of sintered composite systems consisting of glass-alumina $\left(\mathrm{GA}_{4}\right)$ and zirconia $(\mathrm{ZYt})$.

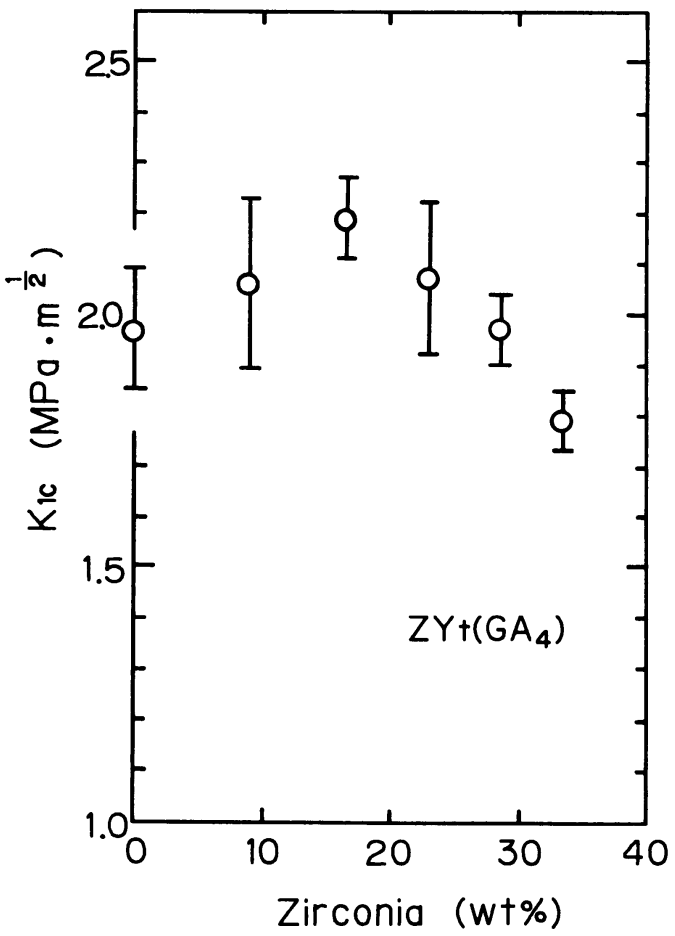

Fig. 8 Relation between fracture toughness $\left(\mathrm{K}_{\mathrm{IC}}\right)$ and zirconia content of sintered composite systems consisting of glass-alumina $\left(\mathrm{GA}_{4}\right)$ and zirconia $(\mathrm{ZYt})$. 
$\mathrm{MPa} \cdot \mathrm{m}^{1 / 2}$, upon dispersion of $23 \mathrm{wt} \%$ zirconia. Bending strength, however, showed no change or even a decrease as zirconia was added.

Such increases in mechanical strength and fracture toughness seem to result from the deflection and bowing of cracks, as well as from the microcracking effect.

\section{REFERENCES}

1) Garvie, R. C., Hannink, R. H. and Pascoe, R. T.: Ceramic steel ?, Nature 258(25) : 703-704, 1975.

2) Pascual, C. and Duran, P.: Subsolidus phase equilibria and ordering in the system $\mathrm{ZrO}_{2}-\mathrm{Y}_{2} \mathrm{O}_{3}, J A m$ Chem Soc 66(1) : 23-27, 1983.

3) Bhathena, N., Hoagland, R. G. and Meyrick, G. : Effects of Particle distribution on transformationinduced toughening in an MgO-PSZ, J Am Ceram Soc 67(12) : 799-805, 1984.

4) Kobayashi, K. and Masaki, T. : PAZ of high mechanical properties, Bull Ceram Soc Japan 17(6): 427 $-432,1982$.

5) Niihara, K. : Brittleness improvement of ceramic materials, Bull Ceram Soc Japan 21(7) : 581-589, 1986. (in Japanese)

6) Watanabe, $\mathrm{H}$. and Chigasaki, M.: The effects of $\mathrm{Al}_{2} \mathrm{O}_{3}$ or $\mathrm{SiO}_{2}$ addition on the thermal shock resistance of $\mathrm{Y}_{2} \mathrm{O}_{3}$-stabilized $\mathrm{ZrO}_{2}, J$ Ceram Soc Japan 94(2): 255-260, 1986. (in Japanese)

7) Ruf, H. and Evans, A. G. : Toughening by monoclinic zirconia, J Am Ceram Soc 66(5) : 328-332, 1983.

8) Heuer, A. H., Claussen, N., Kriven, W. M. and Ruhle, M.: Stability of tetragonal $\mathrm{ZrO}_{2}$ particles in ceramic matrices, J Am Ceram Soc 65(12): 642-650, 1982.

9) Tsukuma, K. and Ueda, K.: High temperature strength and fracture toughness of $\mathrm{Y}_{2} \mathrm{O}_{3}$-partiallystabilized $\mathrm{ZrO}_{2} / \mathrm{Al}_{2} \mathrm{O}_{3}$ composites, $J$ Am Ceram Soc 68(2) : C56-57, 1985.

10) Claussen, N.: Fracture toughness of $\mathrm{Al}_{2} \mathrm{O}_{3}$ with an unstabilized $\mathrm{ZrO}_{2}$ dispersed phase, $J$ Am Ceram Soc 59(1-2) : 49-51, 1976.

11) Nakajima, K. and Kasuga, T. : Zirconia-toughened bioactive glass-ceramics, J Ceram Soc Japan 97(3) : 256-261, 1989. (in Japanese)

12) Miyata, N.:Dispersion toughening of ceramics, Bull Ceram Soc Japan 21(7): 605-612, 1986. (in Japanese)

13) Kon, M. and Kuwayama, N.: Effects of $\mathrm{ZrO}_{2}$ dispersion on properties of glassy porcelains, $J$ J Dent Mat 3(Special B) : 60-61, 1984. (in Japanese)

14) Morena, R., Lockwood, P. E. and Fairhust, C. W. : Enhanced mechanical performance in dental porcelain from $\mathrm{ZrO}_{2}$ addition, J Dent Res 64 : (abstract No. 1088), 1985.

15) Kuwayama, N. and Kon, M.: Studies on sintering of dental porcelains (Part 1), J Japan Soc Dent Appar Mat 22(58) : 101-108, 1981. (in Japanese)

16) McLean, J. W. and Hughes, T. H.: The reinforcement of dental porcelain with ceramic oxides, Brit Dent J 119(6) : 251-267, 1965.

17) Matsuno, Y., Ito, S. and Okuda, H.: Mechanical property evaluation of ceramics, Bull Ceram Soc Japan 16(7) 543-553, 1981. (in Japanese)

18) Kon, M. and Kuwayama, N. : Sintering of dental porcelain (Part 5) Effects of grain size on sintering of glass and alumina, $J J$ Dent Mater 6(1): 16-22, 1987. (in Japanese)

19) Kon, M., Asaoka, K. and Kuwayama, N. : Studies on sintering of dental porcelain (Part 4) Strength and translucency of sintered composite, J J Dent Mater 1(2):118-123, 1982. (in Japanese)

20) Morena, R., Lockwood, P. E. and Fairhust, C. W. : Fracture toughness of commercial dental porcelains, Dent Mater 2: 58-62, 1986.

21) Lange, F. F.: The interaction of a crack front with a second-phase dispersion, Phil Mag 22:983-992, 1970 .

22) Evans, A. G. : The strength of brittle materials containing second phase dispersions, Phil Mag 26 : 1327 $-1344,1972$.

23) Green, D. J. : Stress-induced microcracking at second-phase inclusions, J Am Ceram Soc 64(3): 138141, 1981. 
24) Lange, F. F.: Fracture toughness of $\mathrm{Si}_{3} \mathrm{~N}_{4}$ as a function of the initial $\alpha$-phase content, $J$ Am Ceram Soc 62(7-8) : 428-430, 1979.

25) Becher, P. F. and Wei, G. C. : Toughening behavior in SiC-whisker-reinforced alumina, J Am Ceram Soc 67 : C267-269, 1984.

26) Lange, F. F. : Fracture energy and strength behavior of a sodium borosilicate glass- $\mathrm{Al}_{2} \mathrm{O}_{3}$ composite system, J Am Ceram Soc 54(12) : 614-620, 1971.

27) McMeeking, R. M. and Evans, A. G. : Mechanics of transformation-toughening in brittle materials, $J$ Am Ceram Soc 65(5) : 242-246, 1982.

28) Green, D. J., Nicholson, P. S. and Enbury, J. D. : Crack shape studies in brittle porous materials, $J$ Mater Sci $12: 987-989,1977$.

29) Davidge, R. W. and Green, T. J.: The strength of two-phase ceramic/glass materials, J Mater Sci 3 : 629-634, 1968.

30) Davidge, R. W. : Mechanical Behabiour of Ceramics, Cambridge University Press, Cambridge, 1979 pp. 26-27.

31) Evans, A. G. and Faber, K. T. : Crack-growth resistance of microcracking brittle materials, $J A m$ Ceram Soc 67(4) : 255-260, 1984. 
歯科用陶材の破壊鞄性と強さに及ぼすジルコニア添加の影響

今 政幸, 石川邦夫, 桑山則彦

徳島大学歯学部歯科理工学教室

歯科用陶材のモデルとしてガラスまたはアルミナス陶 材をマトリックスに用い，ジルコニア分散陶材を作製し た。その複合陶材の曲げ強さと破壊勒性 $\left(\mathrm{K}_{1 \mathrm{c}}\right)$ について 検討した。

ガラスマトリックスに各種ジルコニアを $50 \mathrm{wt} \%$ 添加 した複合陶材の曲げ強さと破壊鞄性はガラス単独の場合 に比較して 20〜80\%高くなった。50 wt \%以上ジルコニ アを添加すると強さおよび勒性ともに低下する傾向を示
した。アルミナス陶材をマトリックスとした場合では曲 げ強さの向上はみられなかったが，破壊鞀性については 向上するものが数種出現した。ジルコニア含有量 $16 \sim 23$ wt \% 時に極大值を示し, 鞓性值は最高でガラス焼結体の 2 倍の約 $2.6 \mathrm{MPa} \cdot \mathrm{m}^{1 / 2}$ が得られた。

各種マトリックスにジルコニアを分散した複合陶材の 強さや鞄性が高くなるのはクラックの湾曲と偏向または マイクロクラック効果などが考えられた。

\section{焼付用陶材のガラス転移温度域での粘度について 浅岡憲三，今 政幸，桑山則彦 徳島大学歯学部歯科理工学教室}

陶材の粘度は金属焼付陶材の適合性，すなわち合金と 陶材の好ましい物理的・機械的性質の組み合わせ，焼成 方法と残留応力の関係を決める重要な因子である。一般 に, ガラス転移温度域での陶材の粘度はアレニウス式に より表示される。この粘度が, 応力を加えながら一定速 度で加熱したときに, 陶材が膨張から収縮へ転ずる温度 (変形温度) を測定することにより求まることを, 粘弾 性モデルより導き, 具体的な測定方法を明らかにした。

市販焼付用歯冠色陶材 6 種, オペーク陶材 6 種につい
て活性化エネルギーを上記の方法により測定した。その 結果をもとに焼付用陶材の粘度, 加熱時の変形とガラス の特性温度の関係を比較検討した。また, 陶材の加熱速 度と熱膨張係数の関係について調べた。膨張係数から求 まつたガラス転移域の下限温度が粘度より計算された歪 点と陶材の焼成温度での粘度がガラスの軟化温度の粘度 に一致した。ここで示された測定方法が簡便で信頼性の 高い方法であると結論された。

低屈折率を有するジメタクリレートの応用による光重合

コンポジットレジンの光透過性の改善

平林 茂，平澤 忠

鶴見大学歯学部歯科理工学教室

物性の低下を招く事無く，光重合型コンポジットレジ ンの光透過性を改善するために, 低屈折率を有し, かつ 脂環基またはフッ素置換ビスフェノール基のような高高 な骨格を有する 4 種のジメタクリレートを合成し, それ らを含有した 6 種の試作コンポジットレジンの硬化深さ 並びに物性を調べ, UDMA，Bis-MEPPまたはBis-
GMA を含有した 3 種の対照コンポジットレジンと比較 検討した。

合成したモノマーを含有した実験グループの硬化深さ はUDMA を含有するコンポジットを除いた対照グルー プに比較して深かった。硬化深さはマトリックスモノマ ーとフィラーの屈折率の差が小さくなるに従い増加し 